\title{
Evaluation of Water Heating Systems Through Life Cycle Assessment
}

\author{
Marcel Vechi ${ }^{1}$, Enedir Ghisi ${ }^{1}$
}

\begin{abstract}
The aim of this study is to evaluate water-heating systems through Life Cycle Assessment (LCA). The method involves the application of LCA for the analysis of the global warming potential of water-heating systems that use electricity, gas or solar energy as input. The analysis was performed for a single-family house and also for a four-storey residential building located in three cities in Brazil. The SimaPro computer programme, widely used in the global market when it comes to LCA, was used. The results showed that for the single-family house, the electric shower head is the option that causes less environmental impact for all cities, followed by the solar heater with electric backup and, finally, gas heater with continuous flow. As for the four-storey residential building, the solar heater was the best alternative, followed by the electric shower head, electric boiler, gas heater with continuous flow and, finally, gas boiler. The use phase was responsible for most of the total impact on most systems except for solar heater. The main conclusion is that, in Brazil, water-heating systems that use electricity and solar energy should be preferred over those that use natural gas.
\end{abstract}

Keywords: Life Cycle Assessment, water-heating systems, environmental impact, buildings, computer simulation, SimaPro.

\section{Introduction}

The worldwide energy crisis in the 1970s, associated with the fact that a great part of the electricity consumed in domestic buildings in Brazil is used for heating water for shower (Ghisi, Gosch \& Lamberts, 2007), helped the development of new technologies for heating water, mainly through gas and solar energy (Santos, 2002).

Electric heaters require electricity supplied by thermoelectric, nuclear or hydroelectric plants, especially the last one in Brazil. On the other hand, gas heaters make use of fossil fuels, which produce greenhouse gases. And solar heaters convert clean energy from the sun into heat (Taborianski, 2002). Although solar energy is abundant, it is not completely efficient over the time, which means it cannot stand the hot water consumption of a house through a whole day or a whole year. Therefore, hybrid technologies, such as solar heating with an electric backup system, have been created to cover this downside (Thirugnanasambandam, Iniyan \& Goic, 2010).

In general, the existing energy efficiency labels tend to encourage the use of solar energy in most countries as the consumption of non-renewable sources during the usage phase is low. But what if the whole life cycle of each water-heating system (including materials, manufacturing, distribution and disposal) was analysed? The solar system might not be so efficient if its good performance during usage is counterbalanced by the great amount of energy consumed to produce it. A life cycle assessment of each technology would help to compare the water-heating systems in terms of emissions, energy efficiency,

$\mid{ }^{1}$ Federal University of Santa Catarina, Department of Civil Engineering, Laboratory of Energy Efficiency in Buildings, Florianópolis-SC, Brazil. 
environmental impact etc.

Tsilingiridis, Martinopoulos and Kyriakis (2004) applied the LCA methodology in order to evaluate different configurations of a solar water heater used in single-family houses in Greece and compare them with electricity and natural gas heaters. The environmental impacts associated with the production and utilization of the heaters were assessed by using the Eco-Indicator 99 method. For a house with three people, the use of solar energy with an electric backup corresponded to $38-60 \%$ (depending on the configuration of the system) of the impact caused by the use of electricity. As for the natural gas heater compared to the solar heater, the decrease ranged from $49 \%$ to $69 \%$. The study also proved that steel and copper are the major contributors to the impacts caused by water heating systems.

Taborianski and Prado (2004) conducted a study to evaluate the environmental impact of water heating by means of electricity, natural gas, liquefied petroleum gas and solar heaters through LCA of a single-family house in Brazil. The results showed that the electric shower is the most impacting system considering greenhouse gases emissions, followed by the natural gas and solar system, with approximately half of the electric shower impact, and the best results were obtained for gas heaters with liquefied petroleum gas.

Ardente, Becalli, Cellura and Lo Brano (2005) performed a LCA of a solar heater including extraction, production process, installation, maintenance, transports, and disposal in Italy. The primary energy consumption was estimated as 11.5 GJ. Energy used during the production process and installation represented only $5 \%$ of the total consumption. Transport during the various life cycle phases accounted for $6 \%$. The remaining percentage was used for the production of raw materials. The embodied energy of the solar panel and water tank were the greatest over the life cycle. It is worth mentioning that the use phase was included in the study.

Martinopoulos, Tsilingiridis and Kyriakis (2013) performed a study to identify environmental impacts due to the use of alternative materials in domestic solar hot water systems in Greece. The environmental impacts from the use of the solar systems were considerably lower than those for systems that use electricity. The systems with the best performance through their whole life cycle were not necessarily the same as those with less environmental impact for production and manufacturing. The impact of systems that use electricity was much higher in the use phase.

Zambrana-Vasquez, Aranda-Usón, Zabalza-Bribi, Jañes, Llera-Sastresa, Hernandez and Arrizabalaga (2015) conducted a LCA of water heating systems in order to determine the solution with the lowest environmental impact. For that, 32 types of systems were selected (seven configurations, four inputs and four cases without solar energy) to reach the energy demand for heating water in two houses and two hotels in Aragón, Spain, during twenty years. The results show the impact in some different categories and in energy recovery time. Among the conclusions, it is worth mentioning that the use of biomass represents an environmental benefit when compared to the results of the other inputs in terms of $\mathrm{CO}_{2}$; the use phase of the system is the most representative in the total environmental impact; and biomass has a greater energy recovery time.

As it is possible to notice, not all the studies have similar results. These results can differ, for example, according to the availability of fossil fuels and electricity generation in the 
region or country. However, they produced important information and data that show the relevance of the subject.

\section{Objective}

The objective of this study is to assess the environmental impact of electric, natural gas and solar water heating systems through Life Cycle Assessment (LCA).

\section{Method}

The method consists in applying LCA for the analysis of the global warming potential of different types of residential water heating systems. Depending on the architectural design, there are different distributions for pipes, location of the water tank, electrical installations and other accessories. Thus, a study comparing different types of water heating systems is only justified by adopting a common architectural design.

Some computer tools help to perform this kind of study, allowing a much more complete, fast and trustable analysis. In this case, the tool chosen was the SimaPro software, which is widely used (SimaPro, 2013). This tool contains the Ecoinvent database, created by the Swiss Centre for Life Cycle Inventories aiming to provide more relevant, reliable, transparent and accessible data to users from all over the world.

The materials and processes used for extraction, transformation, manufacturing, supply, use phase and disposal were assumed according to both market research and a similar paper (Taborianski, 2002).

\subsection{The Residential Buildings Selected}

Taborianski (2002) showed that the most common single-family house in Brazil is composed of five rooms (one bathroom), with four inhabitants per house. For this study, a house similar to that used by Taborianski (2002) was used. Fig. 1 shows a view of the house. Its floor plan area is $37.06 \mathrm{~m}^{2}(6.68 \mathrm{~m} \times 5.90 \mathrm{~m})$ with two bedrooms, a living room/kitchen, and a bathroom. Its indoor height measures $2.50 \mathrm{~m}$ and the overall height is $3.73 \mathrm{~m}$. A four-storey multi-family building with similar room distribution was also analysed. Fig. 2 shows a view of the digital model of the multi-family building. It is possible to see the solar panels on the roof.

Fig. 1. A view of the house.

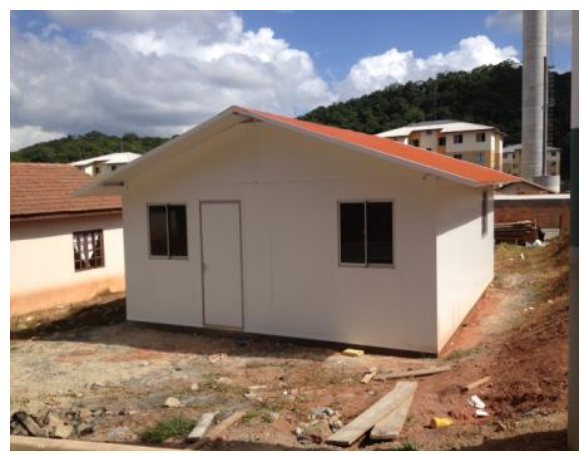




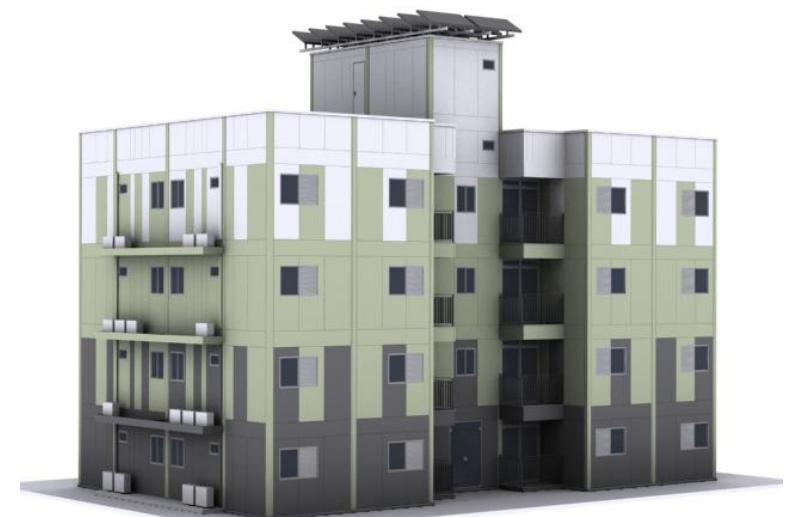

Fig. 2. Digital model of the multi-family building showing the solar panels oriented to north.

\subsection{Input Data}

The layout of the house was analysed and compared to the one assessed by Taborianski (2002). There were significant similarities between them, both in design and in quantity of materials, since they have the same patterns, changing only the construction technology. Thus, the quantity of materials used in the house was obtained from Taborianski (2002). As for the multi-family building, the database used by Taborianski (2002) was also used, but taking into account the differences between a single-family house and a multi-family building.

\subsection{Life Cycle Assessment}

\subsubsection{Goal and Scope}

The LCA was used to compare the global warming potential of water heating systems in both buildings.

Materials not found in the Ecoinvent database were replaced with others with similar characteristics and performance. Transport distances were calculated through market research. The nearest extraction/production plant to the building site was identified for each material or component and then the distance was estimated.

The system studied is defined in terms of the functional unit, reference flow, and boundaries. The functional unit was defined as the production of a certain amount of water heated at a temperature of at least $37^{\circ} \mathrm{C}$. Showers 8 -min long, shower heads with flow rate equal to $0.20 \mathrm{~L} / \mathrm{s}$, and one shower a day per inhabitant were considered over twenty years. The reference flow is the mass of each material used to provide the functional unit.

The boundaries of the system include raw material extraction, materials production, supply (transport), use phase and disposal. The systems operate normally throughout the twenty years period because it was considered that pipes, solar heaters, and gas heaters have a lifespan of twenty years. The exceptions are for the electric shower and its heating element, which need to be replaced often due to their shorter lifespan.

\subsubsection{Processes and inventories}

The water heating systems are composed of heater units, pipes, valves, 
accessories and so on. Thus, the LCA for these systems is more complex, involving multiple devices with different types of materials.

The water heating systems for the single-family house were: electric shower head, solar heater with electric backup and gas heater (continuous flow); and for the four-storey residential building they were: electric shower head, solar heater with electric backup, gas heater (continuous flow), electric boiler and gas boiler.

The considerations on inventories of the electric shower and gas heater with continuous flow are the same for both single-family house and multi-family building. The solar heating system used in the house, which is a compact system, is not suitable for the multi-family building.

The slope of the solar panels was taken equal to the local latitude because, according to Ibrahim, Fardoun, Younes and Louahlia-Gualous (2014), it is the most efficient slope.

An electric shower with power demand equal to $5500 \mathrm{~W}$ in winter and $4600 \mathrm{~W}$ in summer was taken into account. When using an electric shower, there is a significant increase in the house energy demand, requiring the use of larger diameter for cables and conduits. Furthermore, it is necessary to use a specific circuit for the shower.

Eq. 1 was used to estimate the amount of times an equipment needs to be replaced. The average lifespan for the electric shower was taken as ten years and, and as five years for the heating element (Taborianski, 2002).

Amount of replacements $=\frac{\text { Building life span }}{\text { Material life span }}-1$

For extraction, materials with significant impact and used in great quantity in the project were considered in the analysis. For transformation and manufacturing the same procedure as for extraction was used, except for the fact that in manufacturing it is not about materials, but processes.

Supply, the nomenclature used to describe the procedures related to the transport of materials and equipment to the destination place, was estimated as the amount of material (in tonnes) multiplied by the distance of transportation (in kilometres), reaching a result in t.km, according to Eq. 2. The quantity of material was obtained based on the weight of each material as shown in Taborianski (2002) and product catalogues; while the distance was obtained by measuring the distance between the place of origin (factory closest to the destination) and destination (the centre of each city analysed) of each material.

$\mathrm{S}=\mathrm{Q} \times \Delta \mathrm{d}$

Where: $S$ is supply (t.km); $Q$ is the amount of material $(\mathrm{t})$; e $\Delta d$ is the distance of transportation $(\mathrm{km})$.

In the use phase, the energy consumption was calculated using Eq. 3. The power demand was obtained from catalogues. The time the shower is used was estimated considering one 8-minute shower per person per day over 20 years. The efficiency of the electric showers accepted by INMETRO (the Brazilian Institute of Metrology, Quality and Technology) are all greater than 95\%, therefore, 95\% was considered as the efficiency of the shower (INMETRO, 2014).

$\mathrm{E}_{\mathrm{c}}=\frac{\mathrm{P}_{\mathrm{x}} \Delta \mathrm{t}}{\eta_{\mathrm{e}}}$

Where: $E_{c}$ is the electricity consumption $(\mathrm{kWh}) ; P$ is the power demand $(\mathrm{kW}) ; \Delta t$ is the 
time the shower is used (h); and $\eta_{e}$ is the efficiency of the shower.

The environmental impact of a residential water heating system depends on the geographical region in which the house is located. The climatic conditions are the basis for identifying the amount of energy required/available by the equipment that heats the water. In addition, the availability of natural resources in the region and the proximity to factories influenced the impacts related to transportation. Thus, three cities in Brazil were selected, i.e., Natal, Brasillia and Florianópolis. Their geographical coordinates are shown in Table 1.

Table 1. Geographical coordinates of the cities selected for analysis.

\begin{tabular}{lcc}
\hline City & Latitude & Longitude \\
\hline Natal & $05^{\circ} 47^{\prime} 42^{\prime \prime}$ South & $35^{\circ} 12^{\prime} 34^{\prime \prime}$ West \\
Brasília & $15^{\circ} 46^{\prime} 46^{\prime}$ South & $47^{\circ} 55^{\prime} 46^{\prime}$ West \\
Florianópolis & $27^{\circ} 35^{\prime} 49^{\prime}$ South & $48^{\circ} 32^{\prime} 58^{\prime \prime}$ West \\
\hline
\end{tabular}

The energy consumption in each city was calculated considering the use of the shower as indicated in Table 2. The green colour means that the water will be heated because it is winter and hot water is needed, yellow means that warm water may be needed (spring and autumn) and red means that there is no need for warm or hot water (summer).

Table 2. Shower switch positions throughout the year.

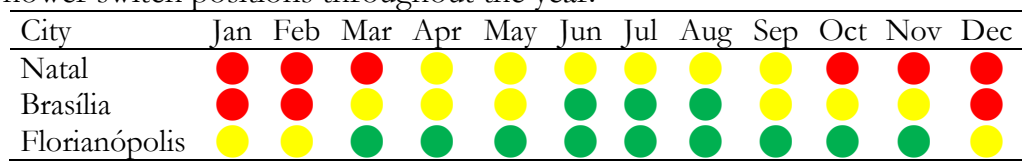

Unfortunately, SimaPro does not have a database for disposal scenario in Brazil. Thus, it was considered that all of the materials are disposed of into landfills, which is the destination of the great majority of solid wastes in Brazil. The gas heater (continuous flow) used in this study has a maximum consumption of natural gas equal to $1.78 \mathrm{~m}^{3} / \mathrm{h}$ and a minimum equal to $1.12 \mathrm{~m}^{3} / \mathrm{h}$. CPVC pipes were used for hot water distribution to reduce costs. Metal pipes were used only for the distribution of gas to the appliance. In this system, it was assumed natural gas as input for the heater. It does not use electricity because there are neither sensors nor electronic ignition in the model chosen. Extraction, transformation, manufacturing, supply and disposal follow the same standard as the electric shower. For the use phase, the energy consumption was calculated according to Eq. 4. The gas consumption was obtained from the manufacturer's catalogue. The minimum efficiency of the gas heaters accepted by INMETRO is $80 \%$, therefore, $80 \%$ was considered as the efficiency of the gas heater (INMETRO, 2014).

$\mathrm{E}_{\text {gas }}=\frac{\mathrm{C}_{\mathrm{x}} \Delta \mathrm{t}}{\mathrm{Y}} \times \mathrm{M}$

Where: $E_{\text {gas }}$ is the energy consumption $(\mathrm{MJ}) ; C$ is the gas consumption $\left(\mathrm{m}^{3} / \mathrm{h}\right) ; \Delta t$ is the time the shower is used (h); $Y$ is the yield; and $M$ is the amount of $\mathrm{MJ}$ produced by $1 \mathrm{~m}^{3}$ of natural gas $\left(38.7 \mathrm{MJ} / \mathrm{m}^{3}\right)$.

The gas consumption in each city was calculated following the same patterns shown in 
Table 2. In this case, the green light means that the water will be heated using the maximum consumption of gas, yellow indicates minimum consumption of gas and red indicates that the heater is turned off.

As for the solar heating with electric backup for use in the single-family house, it was considered a thermosyphon water heater with no need for a pump for water circulation. A 200-litre boiler placed very close to the solar panels on the roof of the house is also part of the system. Copper pipes were used for hot water, since in the solar system the hot water temperature can exceed the maximum temperature supported by plastic pipes. The required solar panels area was estimated using Eq. 5.

$\mathrm{A}=\frac{\mathrm{Q}}{\mathrm{IxY}}$

Where: $A$ is the required solar panels area; $I$ is the average solar radiation over the winter months $\left(\mathrm{kWh} / \mathrm{m}^{2}\right.$.day); $Q$ is the required energy, obtained using Eq. 3 considering the highest demand $(\mathrm{kWh} /$ day); and $Y$ is the yield (average of $50 \%$ in INMETRO approved panels).

The solar radiation is collected, converted into heat and transferred to the water, which is directed to the boiler. In situations with several days without sunlight or low radiation, an auxiliary electricity heater is activated. This heater consists of a $2000 \mathrm{~W}$ heating element located inside the boiler. The electricity consumption during the use phase of this system will be only the consumption of the heating element to supply the demand that exceeds the energy generated by the solar panel during a foggy period.

For the use phase, Eq. 5 was used to calculate the radiation required to supply the hot water demand. Radiasol 2 computer programme gives the monthly available radiation in one place through its geographical coordinates (Radiasol 2, 2014). Thus, an annual simulation for each city allows checking if the demand for radiation is met or not. When the demand was not met, the energy not supplied by the solar heating system was identified and, using Eq. 6, the contribution of the heating element during the system life cycle was estimated.

$\mathrm{C}=\frac{\mathrm{E}_{\mathrm{a}}}{\mathrm{Et}} \times 100$

Where: $C$ is the contribution of the heating element (\%); $E_{a}$ is the energy not supplied by the solar heating system $(\mathrm{kWh})$; e $E_{t}$ is total energy consumption $(\mathrm{kWh})$.

In the solar heater for the multi-family building, it was also considered a thermosyphon heating system. Two 500-litre boilers placed very close to the solar panels on the roof of the building are also part of the system. The sizing was conducted in the same way as for the house. In situations with several days without sunlight or low radiation, an electric heater was activated. This heater consists of a $2500 \mathrm{~W}$ heating element located inside each boiler. The rest of the considerations follow the same patterns as the house inventory.

For the electric boiler of the multi-family building, a 1000-litre 5000W power horizontal boiler was selected to meet the hot water demand. The boilers input power is equal to 2500W in energy-saving mode.

Energy consumption was obtained using Eq. 3, considering boiler efficiency equal to $80 \%$ and other details are the same as those for electric shower, changing only the maximum and minimum powers.

For the gas boiler, a 1000 -litre gas-fired power station with $4.9 \mathrm{~m}^{3} / \mathrm{h}$ of maximum natural gas consumption and $2.0 \mathrm{~m}^{3} / \mathrm{h}$ of minimum consumption was selected. 
The energy consumption was obtained using Eq. 4, and other details are the same as those for the gas heater (continuous flow).

\subsubsection{Impact Assessment}

In this study, the impacts were taken into account using the method "IPCC 2007 GWP 100a", which contains the climate change factors of IPCC (Intergovernmental Panel on Climate Change) with a timeframe of 100 years. This method includes only the global warming potential impact category, which measures the global warming potential of the system. Thus, all processes and materials detailed in the inventory will have a certain impact in $\mathrm{kg} \mathrm{CO}_{2} \mathrm{eq}$, and the sum of these values will be the total impact caused by the system (IPCC, 2013).

\subsubsection{Interpretation and Reporting}

The interpretation is presented in section 4 showing a comparison of the environmental impact among the systems.

\section{Results}

\subsection{Functional Unit}

The functional unit for the house is the production of 2,803,200 litres of hot water at a temperature greater than or equal $37^{\circ} \mathrm{C}$ over a 20 -year period. In order to meet this demand, the shower heads need to be replaced once and their heating element, three times. As for the multi-family building, the functional unit is the production of 44,851,200 litres of hot water, with 16 shower replacements and 48 heating-element replacements.

\subsection{Solar Heating System Design}

The results for the solar heating system are shown in Table 3.

Table 3. Solar heating systems design.

\begin{tabular}{lcccccc}
\hline \multirow{2}{*}{ Parameters } & \multicolumn{3}{c}{ Single-family } & \multicolumn{2}{c}{ Multi-family } \\
\cline { 2 - 7 } & Natal & Brasília & Florianópolis & Natal & Brasília & Florianópolis \\
\hline Energy demand $(\mathrm{kWh} /$ day) & 2.58 & 3.09 & 3.09 & 41.28 & 49.44 & 49.44 \\
Solar radiation $\left(\mathrm{kWh} / \mathrm{m}^{2}\right.$.day) & 4.67 & 4.67 & 3.00 & 4.67 & 4.67 & 3.00 \\
Solar panel area $\left(\mathrm{m}^{2}\right)$ & 1.10 & 1.32 & 2.06 & 17.68 & 21.17 & 32.96 \\
\hline
\end{tabular}

For the house, the solar panel areas ranged from $1.10 \mathrm{~m}^{2}$ to $2.06 \mathrm{~m}^{2}$ according to the city. Despite this variation, a solar panel with $1 \mathrm{~m}^{2}$ was used to comply with the original design. As for the multi-family building, the solar panel areas ranged from $17.68 \mathrm{~m}^{2}$ to $32.96 \mathrm{~m}^{2}$ with an average equal to $24 \mathrm{~m}^{2}$. For this system, according to the original design 16 solar panels with $1.5 \mathrm{~m}^{2}$ each were used, with a total area of $24 \mathrm{~m}^{2}$. Therefore, it was decided to use the same area for all the cities under study because the builder uses the same pre-fabricated components. 


\subsection{Inventory}

All inventories were made, but they will not be shown herein due to space limitations. For the use phase, the energy consumption in Florianópolis was much greater than in Natal. This is due to the fact that Florianópolis is located in a colder region and the electric shower is used at maximum power for most of the year. Brasília has an intermediate consumption.

The use phase of the solar heater has some peculiarities. By applying Eq. 3 to obtain the heat demand in each city, it was observed that Natal requires energy demand equal to $2.58 \mathrm{kWh} /$ day over winter and fall, Brasília $3.09 \mathrm{kWh} /$ day over winter and 2.58 $\mathrm{kWh} /$ day over autumn and spring, and Florianópolis $3.09 \mathrm{kWh} /$ day over autumn, spring and winter, and $2.58 \mathrm{kWh} /$ day over summer. These results, as well as the necessary solar radiation, are shown in Table 4.

When the energy demand is not reached, the energy not supplied by the solar heating system is identified; such energy is due to the contribution of the heating element. According to Eq. 6, for Natal, the heating element accounts for 3\% of the hot water demand, Brasília for 10\% and Florianópolis for 25\% (Table 5). The same procedure was also applied to the multi-family building. The contribution of $1 \%$ for Natal and Brasilia is applied only to cover cloudy days, since the solar heating system covers $100 \%$ of the energy demand.

Table 4. Energy demand and solar radiation available throughout the year.

\begin{tabular}{|c|c|c|c|c|c|c|}
\hline Demand & Building & City & Summer & Autumn & Winter & Spring \\
\hline \multirow{6}{*}{ Energy demand (kWh/day) } & \multirow{3}{*}{$\begin{array}{l}\text { Single- } \\
\text { family }\end{array}$} & Natal & - & 2.58 & 2.58 & - \\
\hline & & Brasília & - & 2.58 & 3.09 & 2.58 \\
\hline & & Florianópolis & 2.58 & 3.09 & 3.09 & 3.09 \\
\hline & \multirow{3}{*}{ Multi-family } & Natal & - & 41.28 & 41.28 & - \\
\hline & & Brasília & - & 41.28 & 49.44 & 41.28 \\
\hline & & Florianópolis & 41.28 & 49.44 & 49.44 & 49.44 \\
\hline \multirow{6}{*}{$\begin{array}{l}\text { Solar radiation available } \\
\left(\mathrm{kWh} / \mathrm{m}^{2} . \text { day }\right)\end{array}$} & \multirow{3}{*}{$\begin{array}{l}\text { Single- } \\
\text { family }\end{array}$} & Natal & - & 5.16 & 5.16 & - \\
\hline & & Brasília & - & 5.16 & 6.18 & 5.16 \\
\hline & & Florianópolis & 5.16 & 6.18 & 6.18 & 6.18 \\
\hline & \multirow{3}{*}{ Multi-family } & Natal & - & 3.44 & 3.44 & - \\
\hline & & Brasília & - & 3.44 & 4.12 & 3.44 \\
\hline & & Florianópolis & 3.44 & 4.12 & 4.12 & 4.12 \\
\hline
\end{tabular}

Table 5. Energy consumption due to the heating element in the solar heating system.

\begin{tabular}{lcc}
\hline \multirow{2}{*}{ City } & \multicolumn{2}{c}{ Heating element contribution (\%) } \\
\cline { 2 - 3 } & Single-family & Multi-family \\
\hline Natal & 3 & 1 \\
Brasília & 10 & 1 \\
Florianópolis & 25 & 8 \\
\hline
\end{tabular}

\subsection{Global Warming Potential}

Figs. 3 and 4 summarize the LCA performed, providing an overview that allows a critical analysis and comparison between the alternatives. Fig. 3 shows the global warming potential of each single-family system for each city, as well as the contribution 
of each phase in the overall impact. Fig. 4 shows the same information for the multifamily building.

For the single-family house, the electric shower has the lowest impact and proved to be the best alternative for the three cities considering the global warming potential. Solar heater has an impact 87\% greater than electric shower in Natal, 53\% in Brasília and 37\% in Florianópolis. This indicates that the use of solar heaters is more indicated to lower latitudes, where the climate is cooler and the demand for hot water is higher. The impact of gas heater compared to electric shower is 110\% greater in Natal, 149\% in Brasília and 198\% in Florianópolis.

In the multi-family building, the lowest impact was obtained for solar heaters followed by electric shower, electric boiler, gas heater (continuous flow), and gas boiler in all cities. The impact of electric shower compared to solar heaters is not significant in Natal; it is only $6 \%$ greater than solar heaters. However, it is significant in Brasília (44\%) and in Florianópolis (67\%). The impact of gas boiler, the worst system in all cities, compared to solar heaters is very significant; it is $115 \%$ greater than electric shower in Natal, $295 \%$ in Brasília and 512\% in Florianópolis.

Extraction is the main responsible for the global warming potential of solar heaters either in single-family houses or multi-family buildings. It represents from $58.5 \%$ to $69.5 \%$ of the total global warming potential. Therefore, solar heaters would cause even less environmental impact if more attention was given to decreasing the energy consumption for extraction of raw material for the production of all solar heater components. On the other hand, the use phase is the main responsible for the global warming potential of all the other water heating systems; it ranges from $37.1 \%$ to $89.9 \%$. Therefore, all the other water heating systems would cause less environmental impact if their efficiency was increased.

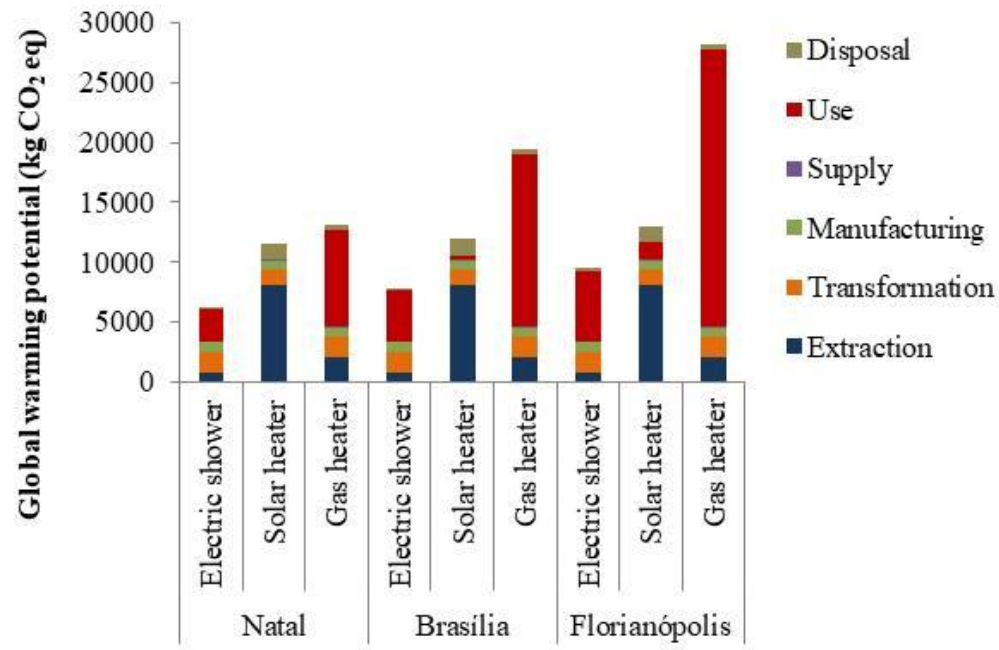

Fig. 3. Global warming potential for each water heating system in the single-family house. 


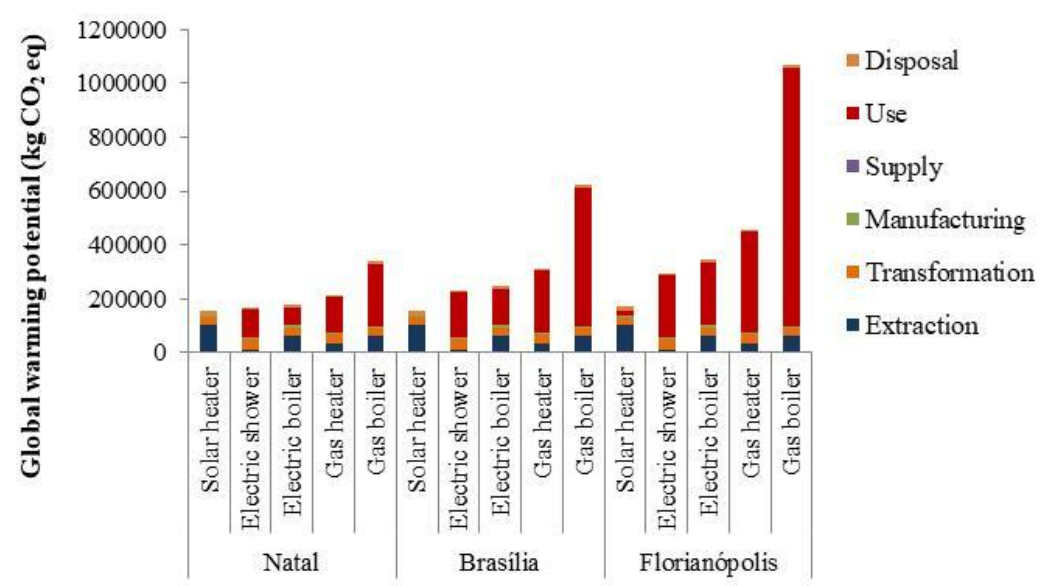

Fig. 4. Global warming potential for each water heating system in the multi-family building.

\section{Conclusions}

The use phase accounts for a large part of the total impact on most systems, except for solar heater systems. For the single-family house, the electric shower is the option with the lowest environmental impact for all cities, followed by solar heater with electric backup and, finally, gas heater (continuous flow). These results were compared with the results of existing works and the conclusions were not similar. For the multifamily building, the solar heater is the less impacting alternative, followed by electric shower, electric boiler, gas heater (continuous flow) and, finally, gas boiler.

As for the global warming potential, it can be stated that there should be a preference for solutions using electricity as input in detriment to solutions with gas. As for solar heaters, the results show that it is a good choice for larger buildings and for lower latitudes (colder weather), where energy demand is greater and the energy saved has an advantage over manufacturing processes and materials. Its performance would still be enhanced if it was properly sized for each city.

\section{References}

Ardente, F., Becalli, G., Cellura, M., \& Lo Brano, V. (2005) Life cycle assessment of a solar thermal collector. Renewable Energy, 30(7), 1031-1054.

Ghisi, E., Gosch, S., Lamberts, R. (2007) Electricity end-uses in the residential sector of Brazil, Energy Policy, 35, 4107-4120.

Ibrahim, O.; Fardoun, F.; Younes, R.; Louahlia-Gualous, H. (2014) Review of water-heating systems: General selection approach based on energy and environmental aspects. Building and Environment, 72, 259-286.

INMETRO - Brazilian Institute of Metrology, Quality and Technology. (2014) Tabelas de consumo/eficiência energética. Retrieved August 10, 2014, from http://www.inmetro.gov.br/consumidor/tabelas.asp.

IPCC - Intergovernmental Panel on Climate Change (2013) Climate Change 2013 - The Physical Science Basis. Retrieved August 1, 2014, from http://www.ipcc.ch/report/ar5/wg1/docs/WGIAR5_SPM_brochure_en.pdf.

Martinopoulos, G.; Tsilingiridis, G.; Kyriakis, N. (2013) Identification of the environmental impact from the use of different materials in domestic solar hot water systems. Applied Energy, 102, 545-555. 
Radiasol 2. (2014) Universidade Federal do Rio Grande de Sul. Retrieved July 1, 2014, from http://www.solar.ufrgs.br/, in Portuguese.

Santos, D. C. (2002) Os sistemas prediais e a promoção da sustentabilidade ambiental [The building systems and the promotion of environmental sustainability]. Ambiente Construido [Built Environment], 2(4), $7-18$, in Portuguese.

SimaPro. 2013. Introduction to LCA with SimaPro. Pre Consultants. Netherlands.

Taborianski, V. M. (2002) Avaliação da contribuição das tipologias de aquecimento de água residencial para a variação do estoque de gases de efeito estufa na atmosfera [Evaluation of the contribution of residential water heating typologies to the variation of the stock of greenhouse gases in the atmosphere]. Master's Dissertation, São Paulo University, Brazil, in Portuguese.

Taborianski, V. M.; Prado, R. T. A. (2004) Comparative evaluation of the contribution of residential water heating systems to the variation of greenhouse gases stock in the atmosphere. Building and Environment, 39, 645-652.

Thirugnanasambandam, M.; Iniyan, S.; Goic, R. (2010) A Review of Solar Thermal Technologies. Renewable and Sustainable Energy Reviews, 14(1), 312-322.

Tsilingiridis, G.; Martinopoulos, G.; Kyriakis, N. (2004) Life cycle environmental impact of a thermosyphonic domestic solar hot water system in comparison with electrical and gas water heating. Renewable Energy, 29(8), 1277-1288.

Zambrana-Vasquez, D.; Aranda-Usón, A.; Zabalza-Bribi, I.; Jañes, A.; Llera-Sastresa, E.; Hernandez, P.; Arrizabalaga, E. (2015) Environmental assessment of domestic solar hot water systems: a case study in residential and hotel buildings. Journal of Cleaner Production, 88, 29-42. 